DOI: 10.38014/ehs-ss.2019.3-I.03

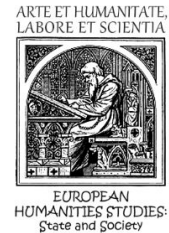

\title{
Nadia SMOLIKEVYCH
}

\section{The teacher's main competencies in modern higher education}

The teacher is a key player in the learning process, whose mission is to provide a supportive and effective learning environment for students' successful adaptation and training in the university. The professional role of teachers was investigated by Selvi (2010), Nimi (2006), Seeberg (2012), Mansilla \& Jackson (2011), Sperandio (2010) and others. The importance of the teacher's intercultural competence in a multicultural environment was considered by Stewart (2007), Sperandio (2007), Villegas \& Lucas (2002). Teaching problems in diverse groups were the subject of the study of Vergheese (2010), Lyon, Bond \& Scudamore (2010), Seeberg (2012) and others.

Despite of a large number of scientific studies on the problems of pedagogy and psychology of higher education (G. Ball, S. Vitvytska, N. Guziy, M. Yevtukh, A. Aleksiuk, A. Hluzman, S. Smirnov, P. Pidkasystyi, etc.) in which they have analyzed the problems of teaching at a higher educational institution, revealed the specifics of the teacher's professional activities, the components of their pedagogical skills, etc., in our opinion, it has not enough been examined in modern scientific literature the issue of the necessary competencies of the teacher to provide a favorable and 
successful training process in the diverse environment for all students of different cultural backgrounds. Knowledge of the peculiarities of preparation, formation, professional and pedagogical activity of teachers contributes to the implementation of positive experience of teaching and learning in democratic environment in Ukrainian universities. Our goal is to reveal the main competencies of an advanced teacher of the university to emphasize the specifics of his educational, scientific activity and professional growth, etc.

According to such Ukrainian researchers, as G. Ball, T. Koshmanova, M. Krasovytskyi, A. Sbruyeva and others, the American model of education, which is characterized by openness, flexibility, democracy and innovation, is effective, efficient, and competitive in the context of contemporary educational challenges. The proper quality of the providing educational services in the university education system of the USA is guaranteed, first of all, by creating the appropriate conditions for the full realization of creative potential by the teachers, ensuring their professional development, etc. Academic freedom provides teachers with wider opportunities for developing new programs, for example, offering new courses in the curriculum, opening new laboratories or teaching and research departments that help to create trustingly demanding relationships between students and teachers with an emphasis on their mutual responsibility for learning outcomes and adherence to pedagogical ethics [4].

Teachers and students should be free in scientific research, study, evaluation, accumulation of new knowledge and its understanding [3].

The main task of the teaching staff is to help the student to achieve success in the adaptive and academic process. The main attention, first of all, is paid to the fact that the teacher is obliged to know his or her subject well; transfer the gained knowledge, skills and experience to others; to carry out individual and group studies for students to improve their general development; evaluate learning outcomes; manage and control the learning process; to determine the educational objectives of educational programs and analyze them; to do the analysis of his or her activities; to promote and contribute effective work of the institution [3]. Qualitative educational services in the United States primarily being provided by "qualitative training of teachers, the insurance of appropriate conditions for the full realization of their creative potential in the system of university education characterized by openness, democracy, innovation and constructivism [3, p. 42]. 
The experience of the American Centers for Pedagogical Excellence and Centers for teaching and learning have developed a lot of programs concentrated on improving pedagogical skills and professional development of teaching staff at universities. They are very valuable for implementation in Ukrainian higher education establishments. Among their main functions there are: consultations of teachers, departments, administrators on problems of methodological support, organization of educational process, relations between teachers and students, between administrators and teachers, etc.; introduction of new educational technologies, technical support for the educational process; organization of courses of pedagogical skill and support of young teachers; conducting scientific and methodical conferences; development of methodical documentation to help teachers. The Centers also hold annual grants contests for support of the development of the methodological and educational process, the introduction of advanced technologies and training of teachers, etc. [8].

Mostly teachers (instructors) are responsible for the organizing an educational process, ensuring a productive educational environment and effective teaching, therefore, they must have a high level of professional competence. Competence is defined as a set of knowledge, skills and experience needed by a person to be successful in a career [6]. The general understanding of the teacher's competences covers three areas: competence in a particular field, pedagogical and multicultural competencies. Let's consider the main components of the teacher's competence, namely: scientific field competence, competence in the research work, competence in the development and implementation of training programs, competence in lifelong learning, multicultural competence, socio-cultural competence, emotional competence, communicative competence, competence in information and communication technologies, managerial competence and ecological competence (fig. 1).

Some competencies are very important for a modern teacher, such as: competence in a certain area of knowledge, competence in research, preparation and implementation of programs, life-long learning, socio-cultural and multicultural competencies, emotional, communicative, information and communication technologies (ICT) competence, managerial and ecological competences (Figure 1). These competences influence on values, behavior, communication, goals and practices, academic process, and professional development support [11]. 


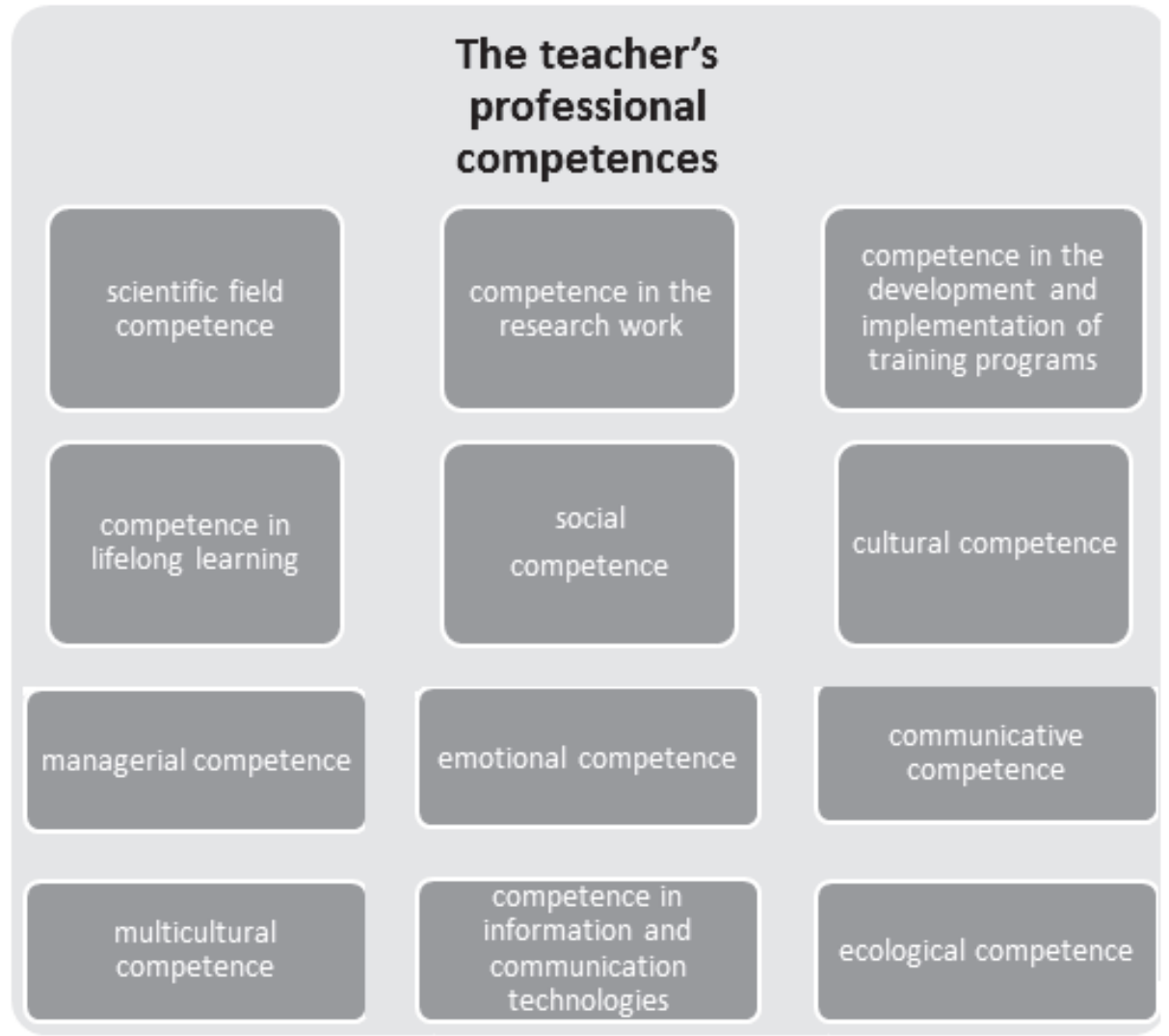

\section{Fig. 1. The components of the teacher's professional competences}

The scientific field competence is the teacher's main competence, which covers academic knowledge in a particular field of science and ensures the performance of professional duties [11].

The competence in the development and implementation of training programs covers program development and implementation, taking into account its contents, approaches to development, planning of the teaching process and monitoring with evaluation, etc. [11].

The research competence involves knowledge of research methodology, development and conducting researches. It promotes "cooperation with colleagues and other professionals interested in education and training, contributes to the research and development of the teacher himself" [9, pp. 36-37]. The lifelong learning competence means the teacher's responsibility for continuing professional development 
[11]. The emotional competence comprises the values of persuasion, motivation and empathy, because of training requires emotional support for participants in the educational process, in which the teacher acts as a consultant, mentor. Students' studying motivation increases if the teacher is acquainted with the methods of providing a favorable atmosphere in the class [11].

The socio-cultural competence outlines knowledge of the sociocultural origin of students, beliefs, values and traditions of different cultures, democracy and human rights, collective or group work organization, cooperation in the multicultural environment and social studies [11]. The communicative competence covers examples of communication, the interaction between the teacher, students, social environment and educational topics. It is necessary for the usage of the language symbols, gestures and professional language [11]. The modern world is characterized by high technological development; therefore, for successful teaching and learning in a highly developed information society, teachers and students need to apply technologies effectively for obtaining and analyzing the information they need; problem-solving and decisionmaking, communicative skills and collaboration, creativity development [13, pp. 6-8].

The Competence in management is important for of teacher's profession. This work requires from him or her to be a good organizer and skilled leader of the educational process, responsible facilitator, mentor and counselor to provide students with the necessary knowledge, practical skills and successful training [11]. In performing this organizational function, the teacher has to act mostly in an authoritarian way, because students are not so competent in studying material to evaluate those or other tasks independently regarding their expediency and effectiveness. They can take part in defining the ultimate goals and order of their achievement by the democratic principles of the learning organization. Universities are also marked by democracy in communicating all participants in the educational process. So, the role of the teacher in this process is to assist the students in their studying process, since the teacher's main goal is to teach students to think critically, make conclusions on their own, but not just memorize the information [1].

The environmental competence is a competence in environmental safety and saving of the planet [11]. In general, knowledge should be useful for the good of society in solving environmental problems, 
nutrition, safety, health, infrastructure development and conflict solving. The teacher as an academic advisor is to help students to determine the learning objectives, develop their plans and study process and implement their studying objectives.

It should be noted that the United States has a great deal of experience in training teachers, which indicates that among all the other competencies required for the profession, multicultural competence is important. This competence requires teachers (instructors, advisors) to be gained in practice, but not traditionally (in classrooms or from information sources about different cultures of the world). It is important for avoiding prejudices about one or another culture, its customs and values. In this case, computer technologies are usually helpful for conducting international online conferences, video lessons on a common theme (historical or cultural) to get to know the point of view of representatives of different cultural and ethnic groups [10].

The American Council on Education has determined that teachers must have the necessary professional knowledge, multicultural competence, and the ability to open students the global world. According to it these qualities form their judgment while communicating with people of different cultures alive or remotely through IT technology, and not only cognitively from information sources [7, 12].

In addition to support qualitative educational services, among the main tasks of higher education of the XXI century are to provide the multicultural competence of students and teachers who work in a diverse environment. According to the scientists' Mule (2012) and Sperandio (2007), intercultural competence should be reflected in curriculum programs (knowledge about different cultures and the ability to work in a diverse environment, intercultural experience, conflict solving, based on the plurality of thoughts, which cover different cultures. Teachers are called to educate students tolerance to different cultures [8, 12].

Universities of the United States have professional development schools, where teachers test different training strategies, techniques and materials in multicultural students groups under the guidance of university advisors and instructors. The teacher has to be both a formal leader and a leader of a group. As a rule, the teacher's business leadership is easy to achieve, it is much more difficult to show emotional leadership depending on how proficient is the teacher to be able to influence the group emotionally in order to establish an individual emotional contact with each other. Therefore, the appearance of teachers, their behavior 
(ability to behave in class properly) and willingness to give modern and actual knowledge to students is very important too.

Multicultural competence covers the following main components: 1) the teacher's awareness of his own cultural identity, views and values, the recognition of his prejudices and stereotypes that influence on his worldview is very important for the formation of an impartial attitude towards students who are representatives of various ethnic and racial groups; 2) eliminating teachers' low expectations about learning abilities of students from other linguistic and cultural backgrounds; 3) knowledge about customs and traditions of different cultures, as they contribute to forming a free of stereotypes understanding of the cultural, social and family lifestyle of students from different backgrounds, as well as making a critical assessment of socio-political, historical and economic circumstances affecting people from different ethnic and racial groups in their everyday lives; 4) skills as attentive, friendly, encouraging attitude and evaluation, understanding of the needs of diverse students, ability to select methodologies appropriate to a specific multicultural group, inclusion of the multicultural component in the educational material [4].

Therefore, the main ability of a teacher (an instructor) is to interest students in the subject, motivate them to study hard, create a favorable environment in the classroom, apply active teaching methods, differentiated learning, communicative approach to learning, taking into account the individual characteristics of each student; to operate with relevant material useful in life and future career, use modern technology during the training sessions. As for the personality characteristics of the teacher, students value most of all openness, kindness, understanding, readiness to help in learning, sense of humor, tolerance, patience, respect, enthusiasm, and multiculturalism [5].

The favorable academic environment provides "internally motivated students' studying process who show interest and need in the process of learning, as well as developing new skills of the organization and selfregulation of their own educational and cognitive activity" [2, p. 125-129].

The main task of the teacher is to create a supportive, motivational educational environment. We agree with T. Ravchyna (2005) on the main provisions of a productive educational environment: "active involvement of everyone in the activity, interpersonal communication, stimulation of activity, support of the initiative; the comfortable environment is provided when there is the lack of coercion, pressure and bias, but the presence of a positive setting, providing opportunities for free consideration, expressing 
own opinions, self-affirmation; respect for the person, recognition of the value of everyone, their views, achievements, and the absence of criticism, abuses, convictions; openness of the environment, it is when participants experience sincerity, the openness in expressing their thoughts, feeling and understanding of the internal state of the individual; positive orientation of the environment that means the development of positive emotions, support well-being, motivations of activity and avoiding past negative experiences, help in realization of the needs of diverse students; relying on principles and rules; acquiring own experience that explains as inducing students to critical, creative thinking, developing their own views instead of just getting ready knowledge" [2, pp. 130-132].

The favorable atmosphere is determined by the democratic features of the interpersonal relations between a teacher and students, the availability of business and comfortable conditions for effective training, set up rules of behavior by a teacher for encouraging students' autonomy and responsibility for their actions and results of their studying.

Teachers should be ready to educate students according to the basics of innovative philosophy of the 21-st century that includes the concepts of social-constructivism (students' self-constructing of new knowledge based on of comprehension of their own experience in democratic academic environment) and post-modernism (student's active role in constructing personal knowledge, the importance of social interaction and authentic tasks in the studying process and importance of diversity support in class).

Summing up the above, we can conclude that it is very important for the Ukrainian higher educational institutions to take on the best practices of the USA regarding the successful organization of the system of work with the teaching staff. The high level of democracy, supporting of a wide range of academic freedoms, and favorable working conditions enable university teachers (instructors, professors) to fully realize their creative potential, identify initiative and achieve the high level of academic and scientific activities. And it has been defined in the article the main competencies needed for teachers working in modern conditions of university education, among them are: scientific field competence, competence in the research work, competence in the development and implementation of training programs, competence in lifelong learning, multicultural competence, socio-cultural competence, emotional competence, communicative competence, competence in information and communication technologies, managerial competence and ecological competence. 


\section{References:}

1. Олендр, Т. М. (2009). Переваги системи вищої освіти США. Наукові праці. Серія: Педагогіка, психологія і соціологія, 5 (155), Ч. I, 57-62.

2. Равчина, Т. (2005). Організація демократичного освітнього середовища. В Т. С. Кошманової (Ред.). Педагогіка для громадянського суспільства: навчальний посібник для студентів педагогічних спеціальностей. Аьвів.

3. Смолікевич, Н. (2009). Викладач у системі університетської освіти: штрихи до професійно-педагогічного портрету. Вісник Аьвівського університету. Серія педагогічна, 25 (4), 40-47.

4. Смолікевич Надія Романівна. (2018). Організаційно-педагогічнезабезпечення адаптації іноземних студентів в університетах США. Дисертація на здобуття наукового ступеня кандидата педагогічних наук (доктора філософіі) за спеціадьністю 13.00.01 «Загадьна педагогіка та історія педагогіки» (011 Освітні, педагогічні науки). Аьвівський національний університет імені Івана Франка, Аьвів, 2001-2005, 3010-2011.

5. Jacobs, Peter. (2014). The 25 Best College Professors In America. Retrieved from http://www.businessinsider.com/best-college-professors-2014-10

6. Katane, Irena et al. (2006). Teacher competence and further education as priorities for sustainable development of rural school in Latvia. Journal of Teacher Education and Training, 6, 41-59.

7. Mansilla, V. B., \& Jackson, A. (2011). Educating for global competence: Preparing our youth to engage the world. Council of Chief State School Officers' EdSteps Initiative \& Asia Society Partnership for Global Learning. Retrieved from http:// www.ccsso.org/Resources/Publications/Educating_for_Global_Competence.html

8. Moule, J. (2012). Cultural competence: A primer for educators, 2nd. Belmont, CA: Wadsworth.

9. Niemi, H., \& Sihvonen R. J. (2006). Research-based teacher education. Researchbased teacher education in Finland: Reflection by Finnish teacher educators. R. J. Sihvonen, \& H. Niemi Eds. Turku: Paionsalama Oy, 31-50.

10. Seeberg, V., \& Minick, T. (2012). Enhancing Cross-cultural Competence in Multicultural Teacher Education: Transformation in Global Learning. International Journal of Multicultural Education, 14 (3). Retrieved from http:// digitalcommons.kent.edu/flapubs/10

11. Selvi, K. (2010). Teachers' competencies. International Journal of Philosophy of Culture and Axiology. January. Retrieved from https://www.researchgate.net/ publication/283961538_Teachers\%27_Competencis

12. Sperandio, J., Grudzinski-Hall, M., \& Stewart-Gambino. H. (2010). Developing an undergraduate global citizenship program: Challenges of definition and assessment. International Journal of Teaching and Learning in Higher Education, $22(1), 12-22$.

13. UNESCO. ICT Standards for Teachers. (2008). Competency Standards Modules. Retrieved from http://unesdoc.unesco.org/images/0015/001562/156207e.pdf 


\section{EUROPEJSKIE STUDIA HUMANISTYCZNE: Państwo i Społeczeństwo}

\section{Transliteration of References:}

1. Olendr, T. M. (2009). Perevahy systemy vyshchoi osvity SShA. Naukovi pratsi. Seriia: Pedahohika, psykholohiia i sotsiolohiia, 5 (155), Ch. I, 57-62.

2. Ravchyna, T. (2005). Orhanizatsiia demokratychnoho osvitnoho seredovyshcha. V T. S. Koshmanovoi (Red.). Pedahohika dlia hromadianskoho suspilstva: navchalnyi posibnyk dlia studentiv pedahohichnykh spetsialnostei. Lviv.

3. Smolikevych, N. (2009). Vykladach u systemi universytetskoi osvity: shtrykhy do profesiino-pedahohichnoho portretu. Visnyk Lvivskoho universytetu. Seriia pedahohichna, 25 (4), 40-47.

4. Smolikevych Nadiia Romanivna. (2018). Orhanizatsiino-pedahohichne zabezpechennia adaptatsii inozemnykh studentiv $\mathrm{v}$ universytetakh SShA. Dysertatsiia na zdobuttia naukovoho stupenia kandydata pedahohichnykh nauk (doktora filosofii) za spetsialnistiu 13.00.01 «Zahalna pedahohika ta istoriia pedahohiky» (011 - Osvitni, pedahohichni nauky). Lvivskyi natsionalnyi universytet imeni Ivana Franka, Lviv, 2001-2005, 3010-2011.

5. Jacobs, Peter. (2014). The 25 Best College Professors In America. Retrieved from http://www.businessinsider.com/best-college-professors-2014-10

6. Katane, Irena et al. (2006). Teacher competence and further education as priorities for sustainable development of rural school in Latvia. Journal of Teacher Education and Training, 6, 41-59.

7. Mansilla, V. B., \& Jackson, A. (2011). Educating for global competence: Preparing our youth to engage the world. Council of Chief State School Officers EdSteps Initiative \& Asia Society Partnership for Global Learning. Retrieved from http:// www.ccsso.org/Resources/Publications/Educating_for_Global_Competence.html

8. Moule, J. (2012). Cultural competence: A primer for educators, 2nd. Belmont, CA: Wadsworth.

9. Niemi, H., \& Sihvonen R. J. (2006). Research-based teacher education. Researchbased teacher education in Finland: Reflection by Finnish teacher educators. R. J. Sihvonen, \& H. Niemi Eds. Turku: Paionsalama Oy, 31-50.

10. Seeberg, V., \& Minick, T. (2012). Enhancing Cross-cultural Competence in Multicultural Teacher Education: Transformation in Global Learning. International Journal of Multicultural Education, 14 (3). Retrieved from http:// digitalcommons.kent.edu/flapubs/10

11. Selvi, K. (2010). Teachers competencies. International Journal of Philosophy of Culture and Axiology. January. Retrieved from https://www.researchgate.net/ publication/283961538_Teachers\%27_Competencis

12. Sperandio, J., Grudzinski-Hall, M., \& Stewart-Gambino. H. (2010). Developing an undergraduate global citizenship program: Challenges of definition and assessment. International Journal of Teaching and Learning in Higher Education, $22(1), 12-22$.

13. UNESCO. ICT Standards for Teachers. (2008). Competency Standards Modules. Retrieved from http://unesdoc.unesco.org/images/0015/001562/156207e.pdf 
The Author

\author{
Smolikevych Nadia, \\ Candidate of Pedagogical Sciences, \\ Assistant, Ivan Franko National University of Lviv, \\ Lviv, Ukraine \\ E-mail:nadiarom@ukr.net
}

Abstracts

SMOLIKEWYCZ NADIJA. Główne kompetencje wykładowcy we współczesnym szkolnictwie wyższym. Artykuł analizuje problemy nauczaniawinstytucjiszkolnictwawyższego, określa specyfikędziałalności zawodowej wykładowcy, składniki umiejętności pedagogicznych oraz kwestie kompetencji nauczyciela, aby zapewnić korzystne $i$ skuteczne środowisko uczenia się. Nacisk kładzie się na specyfike nauczania, działalność badawcza i rozwój zawodowy kadry nauczycielskiej itp. Opisano pozytywne doświadczenia pracy amerykańskich ośrodków pedagogicznych. Określa się główne kompetencje nauczyciela, niezbędne do świadczenia wysokiej jakości ustug edukacyjnych w oparciu o przepisy nowoczesnej pedagogiki, która popiera edukacyjna filozofie konstruktywizmu społecznego i postmodernizmu.

Słowa kluczowe: kompetencje nauczyciela, nowoczesne środowisko edukacyjne, różnorodność, aktywna rola studentów, wspótczesna pedagogika.

СМОЛІКЕВИЧ НАДІЯ. Годовні компетентності викдадача у сучасній вищій освіті. Стаття аналізуе проблеми викладання у закладі вищої освіти, розкривае спещзифіку професійної діяльності викладача, складові педагогічної майстерності та питання необхідних компетентностей викладача для забезпечення сприятливого та успішного навчального середовища. Акцентовано увагу на специфіиі навчальної, наукової діяльності та професійного зростання викладацького складу тощь. Описано успішний досвід роботи американських центрів педагогічної майстерності. Визначено головні компетентності викладача, які є необхінними для надання якісних освітніх послуг на основі положень сучасної педагогіки, що підтримуе освітню філософію соцііл-конструктивізму та постмиодернізму. 


\section{EUROPEJSKIE STUDIA HUMANISTYCZNE: Państwo i Społeczeństwo}

Ключові слова: компетентності викладача, сучасне освітне середовище, різноманітність, активна роль студентів, сучасна педагогіка.

\section{СМОЯИКЕВИЧ НАДЕЖДА. ГАавные компетентности пре-} подавателя в современном высшем образовании. Статья анализирует проблемы преподавания в высшем учебном заведении, раскрывает специфику профессиональной деятельности преподавателя, составляющие педагогического мастерства и вопросы необходимых компетенций преподавателя для обеспечения благоприятной и успешной учебной средь. Акцентировано внимание на спеиифике учебной, научной деятельности и профессионального роста преподавательского состава. Описан успешный опыт работы американских центтов педагогического мастерства. Определены главные колпетентности преподавателя, необходимые для предоставления качественных образовательных услуг на основе положений современной педагогики, что поддерживает образовательную философию социал-конструктивизма и постмодернизма.

Ключевые слова: компетентности преподавателя, современная образовательная среда, разнообразие, активная роль студентов, современная педагогика.

SMOLIKEVYCH NADIA. The teacher's main competencies in modern higher education. The article has analyzed the problems of teaching and learning at a higher educational establishment, reveals the specifics of the teacher's professional activities, the components of his or her teaching skills and deals with the issue on the necessary competencies of the teacher to provide a favorable and successful learning environment for diverse students. The emphasis has been concentrated on the specifics of teaching, research and professional development of the teaching staff, etc. It has also been emphasized the importance of creating the appropriate conditions for the full realization of the creative potential

of teachers, ensuring their professional development, etc. The important characteristics of a favorable university environment have been singled out. It has been noted that teachers and students should be free in scientific research, study, evaluation, accumulation of new knowledge and its understanding. The main tasks, professional abilities and responsibilities of teachers in the global educational environment have been identified in order to help recipients of academic services to succeed in the adaptation and academic process. The successful experience of the American centers 
of pedagogical skill has been described in order to borrow it by the higher education system of Ukraine to ensure the development of the professional and creative potential of the teaching staff of universities. The main competencies of teachers have been determined and described, because they are necessary for providing high-quality educational services based on the educational philosophy of social-constructivism and postmodernism, which support an active role of students, social interaction and diversity in the class.

Keywords: the teacher's competencies, modern educational environment, diversity, students' active role, modern pedagogy. 